地まきホタテガイの成長不良に対する水温および慨濃度の影響

\title{
Effect of Water Temperature and Food Concentration on the Growth of Bottom Cultured Japanese Scallop Mizuhopecten yessoensis, in the Coastal Area of Northeastern Part of Hokkaido, Japan
}

品田晃良

北海道立網走水産試験場。广099-3119 北海道網走市鱒浦 1-1-1

Akiyoshi SHINADA

Hokkaido Abashiri Fisheries Experimental Station. 1-1-1 Masuura, Abashiri, Hokkaido 099-3119, Japan

\begin{abstract}
Effect of temperature and food concentration on the growth of bottom cultured Japanese scallop Mizuhopecten yessoensis, was investigated in the coastal area of northeastern part of Hokkaido, Japan. Fourteen years from 1992 to 2005 were distinguished into good growth years and bad growth years by yield rates of adductor muscle. Although water temperature was not different between good and bad growth years significantly, chlorophyll $a$ concentrations in spring were significantly higher in good growth years than in bad growth years. The predictive model for bad growth years was constructed by spring temperature and chlorophyll $a$ data. The appropriate logistic regression model was selected by AIC method, so that the model using spring chlorophyll $a$ data was adapted. These results suggest that low food concentration in spring causes bad growth to bottom cultured Japanese scallop.
\end{abstract}

Key Words: chlorophyll $a$, growth, logistic regression model, Mizuhopecten yessoensis, monitoring, scallop

\section{はじめに}

オホーツク海に面する北海道北東部の沿岸海域では, 種 苗放流による輪採制のホ夕テガイ漁業（地まき漁業）が行 われている(蔵田 2003)。地まき漁業は, 中間育成により 1 年貝まで育てた稚貝を放流して 3 年後に 4 年貝を漁獲する 漁業であり, この行程は, 各漁協が設置している複数の海 区でそれぞれ別の年に繰り返される。本漁業は, 害敵であ るヒトデ駆除の徹底, 種苗生産技術および放流技術なよ゙の 技術革新により安定性, 生産性とも高水準にある（西浜 1994).

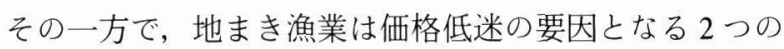
不安定要素を抱えている. 1 つは, 1990 年代前半に問題に なったホタテガイの恒常的な小型化である. その要因とし て, 生残率の向上による生息密度の増加や慨料環境の悪い 沖側への漁場拡大などの人為的要素之（蔵田 1999）, 天然 発生した若年貝の混獲による自然的要素（見かけの小型 化）が考えられている（五嶋・千葉 2001）. 小型化の対策 としては, 放流数と放流場所の調整（蔵田 1999）や生息密 度の高い場所加ら低い場所への移植 (Paturusi et al. 2002) なよ゙がある。 もう 1 つの不安定要素は, 一時的に貝柱歩留 （全重量に占める貝柱重量の割合）が悪くなる成長不良で

Received 3 Jan. 2006 Accepted 29 May 2006
ある. 要因上しては, 大時化, 低水温（成長阻害を引き起 こす）および餌不足なよ゙の環境異变が考えられているが, 環境異变はまれに起こるものなので成長不良と海洋環境と の関係はいまだ不明な点が多い（西浜 1994）.

本研究は, 1992 年から 2005 年までのモニタリングデー 夕を用いて，地まきホ夕テガイの成長不良に対する水温之 餌環境の影響を明らかにすることを目的とした。また，漁 期前の 4 月から 5 月の海洋環境デー夕を用いて，その年が 成長不良となる確率を推定するモデルを作成した。

\section{材料と方法}

調査は, 1992 年から 2005 年に北海道北東部に位置する 紋別漁場で行った (Fig. 1). ホ夕テガイ試料（4年貝）は, 4 月から 11 月にかけて月 2 回の頻度で水深約 $40 \mathrm{~m}$ からホ タテ桁網により採集して, 40 個体について全重量と貝柱重 量の測定を行った。

海洋観測は，ホタテガイ試料の採集と同時に行った. 水 温はSTD（アレック電子AST-1000）で測定した。 クロロ フィル $a$ 測定用試水は, バンドン採水器でホ夕テガイの成 長が最毛良い水深約 $40 \mathrm{~m}$ の底層加ら採水して, GF/C フィルターでろ過したのち分析まで凍結保存した。 クロロ フィル $a$ の抽出は, $n, n$-ジメチルホルムアミド (DMF) で 行い, 濃度は蛍光光度計（ターナーデザイン社 Model 10AU) を用いWelschmeyer 法 (Welschmeyer 1994) で測定し 


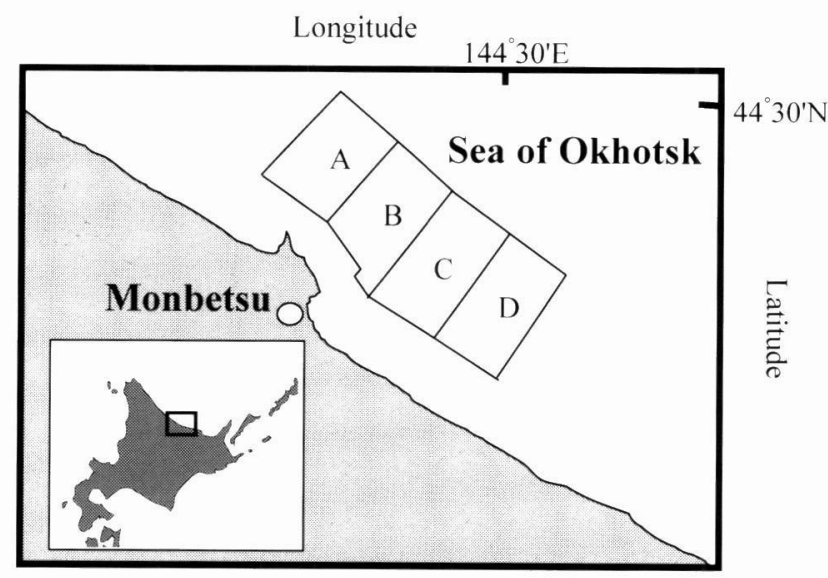

Fig. 1. Scallop culture ground of Monbetsu with the divided culture area (A to D).

た。

ホタテガイの成長状況は，漁期である 6 月から 11 月の

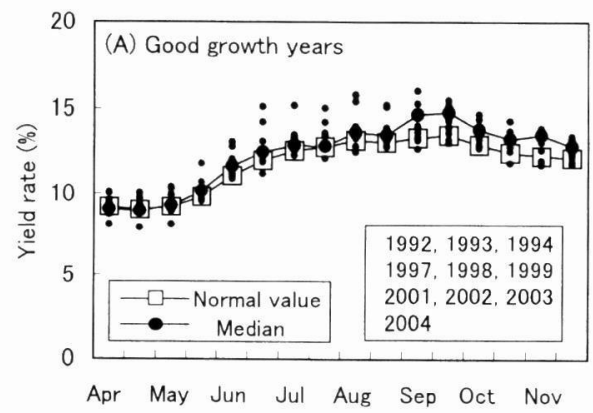

貝柱歩留（貝柱重量/全重量 $\times 100 ）$ で判定した。 6 月から 11 月までの 12 回の調査で, 貝柱歩留が 9 回以上平年值 （1992 年から 2005 年までの算術平均）を下回った年を成長 不良年, それ以外の年を成長良年と区分した（2 項検定：P $=0.5, n=12, p<0.05)$. 4 月から 5 月における成長不良年 と成長良年の水温とクロロフィル $a$ の差は, Mann-Whitney の $U$ 検定で検定した。 また，ロジステック回帰分析に より，漁期前の 4 月から 5 月の水温およびクロロフィル $a$ データで，その年が成長不良年となる確率を推定するモデ ルを作成した. 最適モデルは AIC 法により選択した. モデ ルの定義は以下のと抢り。

$$
\begin{aligned}
& Y=\frac{1}{1+\exp \left[-\left(\beta_{0}+\beta_{1} T+\beta_{2} C h l\right)\right]} \\
& Y: \text { ホ夕テガイの成長状況 }(0: \text { 成長良年, } 1 \text { : 成長不良 } \\
& \quad \text { 年) } \\
& T: \text { 底層水温（4 月から } 5 \text { 月の平均） }
\end{aligned}
$$$$
C h l \text { : 底層クロロフィル } a \text { 濃度 (4月から } 5 \text { 月の平均) }
$$

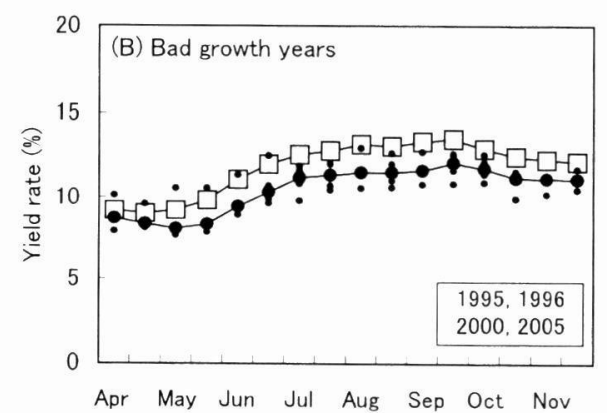

Fig. 2. Seasonal changes in yield rates of adductor muscle. A. Good growth years. B. Bad growth years. Small closed circles show each year value. Normal value is arithmetic average from 1992 to 2005 (open squares). Median is calculated by each value of good and bad growth years (large closed circles).
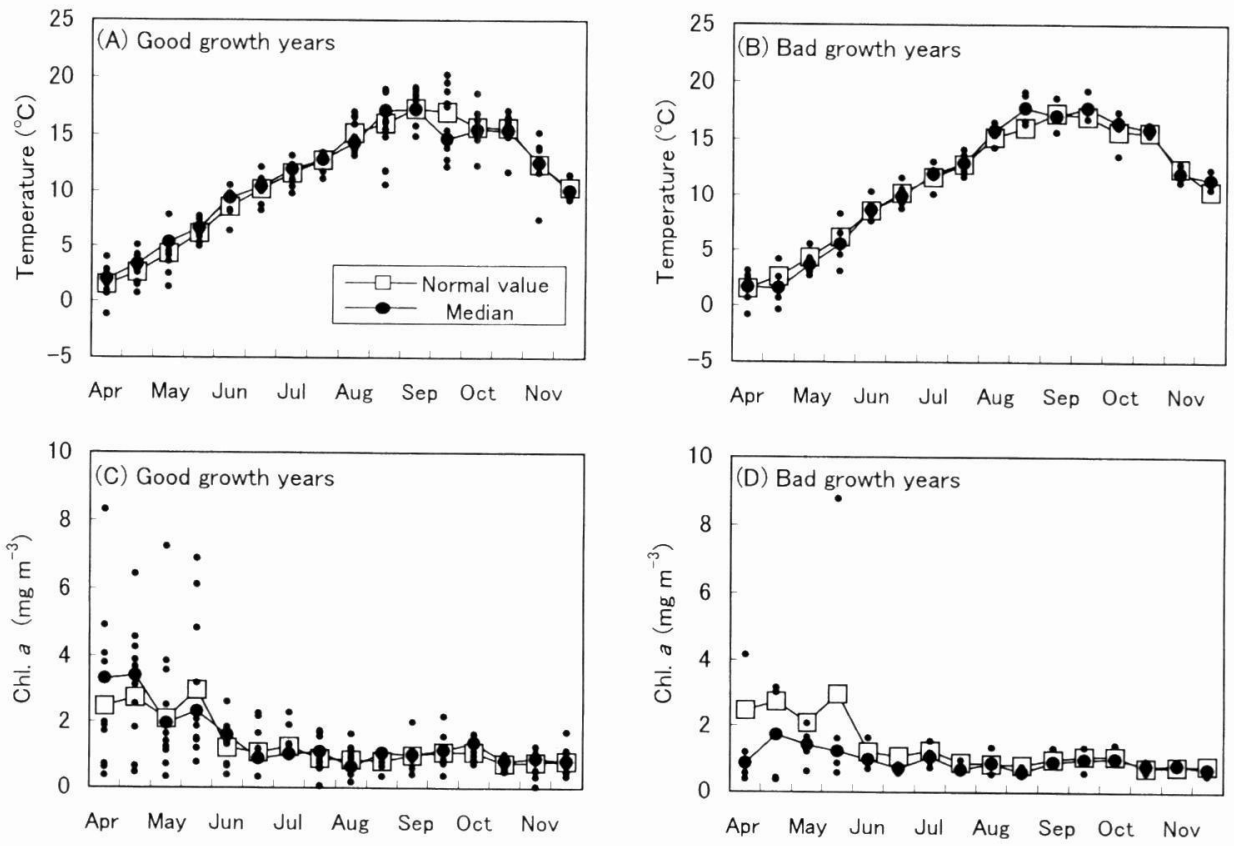

Fig. 3. Seasonal changes in temperature and chlorophyll a concentration of good growth years (A) (C), and bad growth years (B) (D). Small closed circles show each year value. Normal value is arithmetic average from 1992 to 2005 (open squares). Median is calculated by each value of good and bad growth years (large closed circles). 
Table 1. Regression coefficients and summary statistics of the logistic regrassion model. $\beta_{0}$ is the intercept parameter and, $\beta_{1}$ and $\beta_{2}$ are the regression coefficients for temperature and chlorophyll $a$, respectively. In parentheses after each values is the $p$-value. AIC is the Akaike's Infomation Criteria. Sample size is 14.

\begin{tabular}{|c|c|c|c|c|}
\hline \multirow{2}{*}{ Model } & \multicolumn{3}{|c|}{ Coefficients ( $p$-value) } & \multirow{2}{*}{ AIC } \\
\hline & $\beta_{0}$ & $\beta_{1}$ & $\beta_{2}$ & \\
\hline$T$ & $0.633(0.70)$ & $-0.591(0.34)$ & - & 19.7 \\
\hline Chl & $1.047(0.46)$ & - & $-0.944(0.06)$ & 18.0 \\
\hline$T+C h l$ & $1.423(0.43)$ & $-0.865(0.23)$ & $-0.205(0.74)$ & 19.8 \\
\hline
\end{tabular}

T: Temperature, Chl: Chlorophyll a

\section{結果}

貝柱歩留の平年値は，5月より増加して 9 月下旬には最 大值 $(13.5 \%)$ を示した (Fig. 2). 成長良年に打ける貝柱歩 留の中央值は, 漁が始まる6月から 11 月に平年值を上回 る傾向を示したが，成長不良年は，5月以降む増加が緩や かで平年值を下回って推移した。

底層水温の平年值は， 4 月の $1.5^{\circ} \mathrm{C}$ から上昇して 9 月下 旬に最高水温 $\left(17.3^{\circ} \mathrm{C}\right)$ を示した (Fig. 3$)$. 成長良年に打け る底層水温の中央值は，4月から5 月まで平年値を 0.4 $1.0^{\circ} \mathrm{C}$ 高く, 成長不良年は 4 月から 5 月下旬まで最大で $1.0^{\circ} \mathrm{C}$ 低くに推移したが，成長良年と成長不良年に明確な

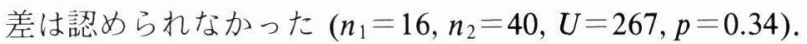

底層クロロフィル $a$ 濃度の平年值は， 4 月加ら 5 月にか けて 2 3 $\mathrm{mg} \mathrm{m}^{-3}$ の高い值を示すが，それ以降は 0.7 1.2 $\mathrm{mg} \mathrm{m}^{-3}$ の低い值であった。成長良年における 4 月から 5 月の底層クロロフィル $a$ 濃度は, 成長不良年に比べ有意に

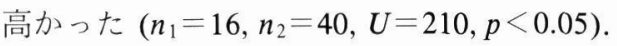

成長不良之なる確率を推定するモデルについて，モデル 選択を AIC 法で行ったところ, 説明变数として底層ク口 ロフィル $a$ 濃度を採用したモデルが選択された (Table 1).

\section{考察}

ホ夕テガイの成長に影響を与える要因として, 水温, 慨 環境, 底質などが考えられている（蔵田 1999）。ホタテガ イの生息水温は, $-1.5^{\circ} \mathrm{C}$ から $23^{\circ} \mathrm{C}$ で（蔵田 2003）, 約 $18^{\circ} \mathrm{C}$ が最も代謝活動が活発になると報告されている（蔵 田 1996)。調査期間中の水温は常に生息水温の範囲内に あったので (Fig. 3), 水温がホタテガイの生理機能にそれ ほど影響を与えていないと考えられる。また，4月から 5 月の水温は, 成長良年と成長不良年で $1^{\circ} \mathrm{C}$ ほどの差しか認 められなかった。北海道北東部のサロマ湖で養殖されてい るホ夕テガイのろ水率は, 水温が $-2^{\circ} \mathrm{C}$ から $10^{\circ} \mathrm{C}$ の範囲 で軟体部 $1 \mathrm{~g}$ 当たり約 $2 l \mathrm{~d}^{-1}$ とほ上んど変化しないこ之 が報告されている（蔵田 1991）。よって，成長良年と成長 不良年でホ夕テガイのろ水率に差はないと考えられる，以 上より，水温が調査期間中の成長不良の要因之なった可能
性は低いと考えられる。

一方, 餌濃度については 4 月から 5 月にかけて明確な違 いが見られた。すなわち, 成長良年は, 春季ブルームの影 響上考えられる 2 3 $\mathrm{mg} \mathrm{m}^{-3}$ の高いクロロフィル $a$ 濃度 を示したが，成長不良年は，クロロフィル $a$ 濃度の顕著な 增加は認められなかった (Fig. 3). 4 月から 5 月は, 本海域 に打ける植物プランクトンの大增殖期にあたり（西浜 1989)，ホ夕テガイがエネルギーを貝柱に蓄える時期と考 えら机ている(蔵田 1996)。水温が低い4 月加 5 月の期 間は, 前述のようにホ夕テガイの濾水率がほ上んど変化し ないので, ホ夕テガイの摂餌量は現場の餌濃度に比例す ると考えられている(蔵田 1991)。これは, 成長不良年上 なる確率を推定するモデルで, 底層クロロフィル $a$ 濃度 が説明変数として選択されていることからもうかがえる (Table 1). 以上より, 4 月から 5 月の餌不足が, ホ夕テガ イの椇餌量を減少させて, その結果, ホ夕テガイは貝柱に エネルギーが蓄えることができず成長不良が発生する上考 えられる。

本研究では, 地まきホ夕テガイの成長不良に対する要因 として, 水温と餌環境についてのみ解析を行ったが, 大時 化，底質抒よび流量等の海洋環境の影響についても今後明 らかにしていく必要がある。 また，4月から5月の海洋環 境データで, その年が成長不良年となる確率を推定するた めに使用したロジスティック回帰分析は，データセットが 增えるほどパラメー夕推定の精度が向上するので, より精 度の良いモデルを構築するためにも継続したモニタリング が必要である.

謝 辞：术稿を終わるにあたり，野外調查打よび測定にご協力 いただいた紋別漁業協同組合，網走地区水産技術普及指導所なら びに網走水産試験場資源増殖部の方々に謹んで御礼申し上げま す。また，本稿をま之めるにあたり有益なコメントをいただいた レフリーに謹んで御礼申し上げます。なお，本研究は北海道加北 海道ほたて漁業振興協会より受託している「ホ夕テガイ成長モ二 タリング調査」の一部である。

\section{引用文献}

五嶋聖治・十葉 晋 2001．I. ホ夕テガイの成長におよぼす天然 発生貝に関する研究. 水産学術研究・改良補助事業報告 (平成 12 年度), 北水協会, 北海道, pp. 58-62. 
蔵田 護 1991. サロマ湖における垂下養成ホタテガイの掑餌量. 北海道立水産試験場研究報告, 37: 37-57.

蔵田 護 1996. オホーツク海における放流ホタテガイの呼吸量. 北海道立水産試験場研究報告, 49: 7-13.

蔵田護 1999. 北海道オホーツク海沿岸におけるホタテガイの 小型化の実態とその原因. 北海道立水産試験場研究報告, 54: 25-32.

蔵田 護 2003. 73. ホタテガイ Mizuhopecten yessoensis (Jay). 水島 敏博・鳥澤 雅（監修），上田吉幸・前田圭司・嶋田 宏・鷹見 達也 (編), 新北のさかなたち, 北海道新聞社, 北海道, pp. 290295.

西浜雄二 1994. オホーツクのホタテ漁業, 北海道大学図書刊行
会, 北海道, $218 \mathrm{pp}$.

西浜雄二・蔵田 護・多田匡秀 1989. サロマ湖・能取湖・網走 沖におけるクロロフィル量の季節变化. 水産海洋研究, 53: 5254.

Paturusi, A., S. Chiba and S. Goshima 2002. The magnitude of natural recruitment in a cultured population of Japanese scallop Patinopecten (Mizuhopecten) yessoensis on Yubetsu seabed (Japan), Sea of Okhotsk. Benthos Research, 57: 69-75.

Welschmeyer, N. A. 1994. Fluorometric analysis of chlorophyll $a$ in the presence of chlorophyll $b$ and pheopigments. Limnology and Oceanography, 39: 1985-1992. 